\title{
ECOTOXICOLOGICAL ASSESSMENT OF SEDIMENTS FROM THE SANTOS AND SÃO VICENTE ESTUARINE SYSTEM - BRAZIL
}

\author{
Augusto Cesar ${ }^{1,2}$; Camilo Dias Seabra Pereira ${ }^{2,3}$; Aldo Ramos Santos ${ }^{2}$; Denis Moledo de Sousa Abessa ${ }^{4}$; Nuria \\ Fernández ${ }^{1}$; Rodrigo Brasil Choueri ${ }^{1} \&$ Tomaz Angel DelValls ${ }^{l}$ \\ ${ }^{1}$ Universidad de Cádiz \\ Facultad de Ciencias del Mar y Ambientales - Departmento de Química Física \\ (CP. 11510, Puerto Real, Cádiz. Spain) \\ E-mail: aucesar@unisanta.br \\ ${ }^{2}$ Universidade Santa Cecília - UNISANTA \\ Departamento de Ecotoxicologia \\ (Rua Oswaldo Cruz, 266, 11045-907 Santos, SP, Brasil) \\ ${ }^{3}$ Instituto Oceanográfico da Universidade de São Paulo \\ Laboratório de Ecotoxicologia Marinha \\ (Praça do Oceanográfico, 191, 05508-120 São Paulo, SP, Brasil) \\ ${ }^{4}$ Universidade Estadual Paulista Júlio de Mesquita Filho - UNESP \\ Campus do Litoral Paulista -São Vicente \\ (Praça Infante Dom Henrique, s/n, 11330-900, São Vicente, SP, Brasil)
}

\begin{abstract}
A B S T R AC T
Sediments represent an important repository of pollutants and a source of contamination for the aquatic food web. Toxicity tests using amphipods as test-organisms have been employed in the assessment of marine and estuarine sediments, together with chemical analyses. The present work aimed to evaluate the quality of sediments from six stations situated in the Santos and São Vicente Estuarine and Harbour System (São Paulo - Brazil) using acute whole sediment toxicity tests with amphipods (Tiburonella viscana) and chemical analyses of metals, PCB's, and PAH's. Other sediment parameters, such as organic carbon and grain size distribution were also analysed. Higher contamination levels were observed in the internal portion of the estuary, where Santos harbour and the industrial zone are located. The toxicity tests showed significant adverse results for most of the samples tested, and the sediments from the internal portion of the estuary presented the highest toxicity. The principal component analyses (PCA) indicated a close relationship between sediment contamination and toxicity. Positive correlation of these factors in the samples studied was used to establish the ranges of the chemical concentrations associated with adverse effects. Such ranges allowed the estimation of preliminary effect threshold values for sediment contamination, by means of multivariate analysis. These suggested values are: $\mathrm{Cu}, 69.0 ; \mathrm{Pb}, 17.4 ; \mathrm{Zn}, 73.3\left(\mathrm{mg}^{\left.-\mathrm{kg}^{-1}\right)}\right.$; PAHs, $0.5\left(\mathrm{mg}^{\left.-\mathrm{kg}^{-1}\right)}\right.$ and PCBs, 0.1 $\left(\mu \mathrm{g} \cdot \mathrm{kg}^{-1}\right)$.
\end{abstract}

\section{RESUMO}

O sedimento representa um importante depósito de contaminantes e uma fonte de contaminação para a cadeia alimentar aquática. Testes de toxicidade usando anfípodos como organismos-teste são empregados para avaliar sedimentos marinhos e estuarinos, juntamente com análises químicas. O presente trabalho tem como objetivo avaliar a qualidade de sedimentos de seis estações situadas no Sistema Estuarino e Portuário de Santos e São Vicente (São Paulo-Brasil), usando testes de toxicidade aguda com sedimento com anfípodos (Tiburonella viscana) e análises químicas de metais, PCB, e PAH. Outros parâmetros do sedimento foram analisados, como carbono orgânico e granulometria. Foram observados níveis de contaminação mais altos na porção interna do estuário onde se localiza o Porto de Santos e a zona industrial. Os testes de toxicidade mostraram resultados adversos significantes para a maioria das amostras testadas, e os sedimentos da porção interna do estuário apresentaram toxicidade mais alta. As análises de componentes principais indicaram uma relação forte entre contaminação do sedimento e toxicidade. As correlações positivas destes fatores nas amostras estudadas foram usadas para estabelecer os pesos das concentrações químicas que estão associadas com os efeitos adversos. Tais análises permitiram estimar valores limiares de efeito para a contaminação de sedimento através de análises multivariadas, identificando os contaminantes associados com o efeito biológico. Estes valores sugeridos são: $\mathrm{Cu}, 69.0$; Pb, 17.4; Zn, 73.3(mg.kg $\left.{ }^{-1}\right)$; PAHs, $0.5\left(\mathrm{mg}^{\mathrm{kg}} \mathrm{kg}^{-1}\right)$ e PCBs, $0.1\left(\mu \mathrm{g} . \mathrm{kg}^{-1}\right)$.

Descriptors: Toxicity tests, Contamination; Multivariate analysis, Sediment quality values, Santos and São Vicente Estuarine System.

Descritores: Testes de toxicidade, Análises multivariadas, Valores de qualidade de sedimento, Sistema Estuarino de Santos e São Vicente.

$\overline{\text { Contr. } N^{o} 872}$ do Inst. oceanogr. da Usp 


\section{INTRODUCTION}

Most of the anthropogenic chemicals and waste materials, including toxic organic and inorganic chemicals, contribute to the degradation of aquatic environments. This is particularly important for the coastal and estuarine ecosystems, which are constantly affected by multiple contamination sources.

The Santos and São Vicente Estuarine System (Fig.1) is located on the coast of the State of São Paulo, Brazil $\left(23^{\circ} 30^{\prime} 5^{\prime}\right.$ 'S - $24^{\circ} \mathrm{S} ; 46^{\circ} 05^{\prime} \mathrm{W}$ $46^{\circ} 30^{\prime} \mathrm{W}$ ), and in the centre of the Baixada Santista Metropolitan Region. The largest Brazilian industrial complex is installed in this densely urbanized region, with the predominant presence of its petrochemical, steel, and fertilizer industries - the major Latin American port that of Santos, is also to be found here. This region is economically important not only because of its industrial development, but also because of its natural tourist and fishery activities. Apart from its outstanding economic importance, the region has also considerable environmental relevance since the Santos and São Vicente Estuarine System is surrounded by mangrove swamps, which account for $43 \%$ of the total mangrove area of the state of São Paulo (Lamparelli et al., 2001).

Although it is of great ecological importance, the high density of its urbanization, the presence of multiple potentially polluting industries and its port activities all greatly affect the environmental quality of the Santos and São Vicente Estuarine System. Large quantities of contaminants are discharged into this estuary, resulting in high sediment contamination and toxicity (Lamparelli et al, 2001; Abessa et al., 1998; Abessa, 2002; Weber \& Bícego, 1987; Boldrini \& Navas-Pereira, 1987; CETESB, 1985; Fúlfaro et al., 1983).

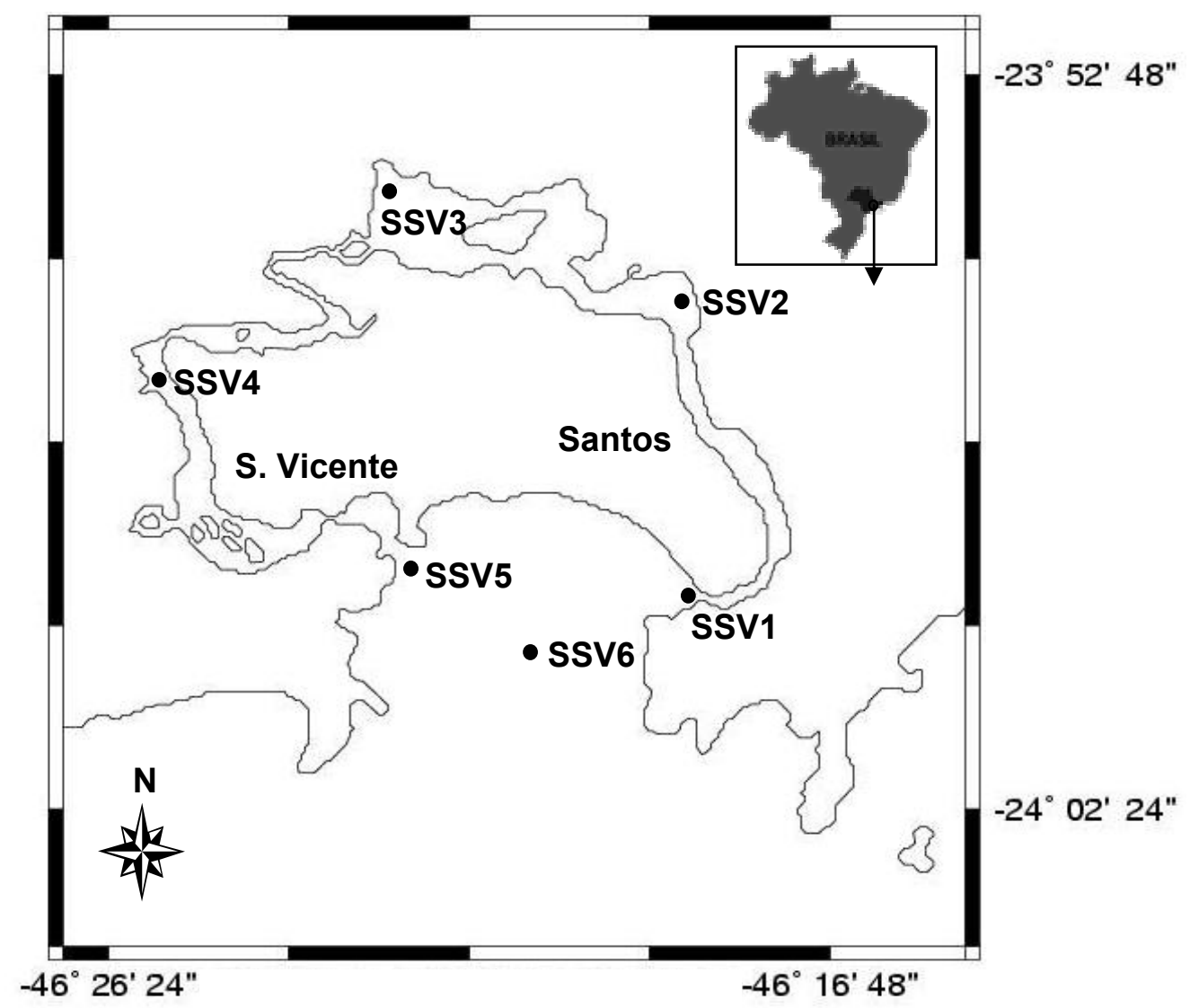

Fig. 1. Geographical location and position of the sampling points in the Santos and São Vicente estuarine system. 
Sediments may accumulate contaminants in concentrations higher than those observed in the water column, thus producing harmful effects on the benthic biota and the organisms that feed on the benthos or the sediment. Due to its ecological importance and the persistence of pollutants in this environmental compartment, the sediment is more adequate for monitoring in environmental evaluations (Swartz et al., 1982).

Many different approaches may be used in sediment quality assessment. Among them, chemical analyses and toxicity tests are the most commonly used around the world. Chemical analyses consist of listing the contaminants and quantifying their respective concentrations, and provide information on the presence of substances at such levels as may cause problems (Burton Jr., 1992). Toxicity tests are considered effective tools for providing direct, quantifiable evidence of the biological consequences of contamination, and can be used to estimate the interactive toxic effects of complex contaminant mixtures in the aquatic environment (Burton Jr., 1992). Infaunal amphipods are suitable and are strongly recommended as test organisms in sediment toxicity bioassays (U.S. EPA, 1994; ASTM, 1997), being used world wide in ecotoxicological evaluations of marine sediments (Gannon \& Beeton, 1971; Swartz et al., 1982; Nipper et al., 1993; Carr et al., 1996; Abessa et al., 1998; 2001; DelValls et al., 1998; Cesar et al. 2000; Hunt et al., 2001a; b).

The main objective of this study was to evaluate the quality of sediments from different sites affected by different sources of contamination, using an integrated method that applies both sediment chemistry and toxicity assessment. A further objective was to derive preliminary site-specific quality values for the Santos and São Vicente Estuarine System using multivariate analysis, for the ranges of chemical concentrations associated with adverse biological effects.

\section{Material and Methods}

\section{Approach}

This study was conducted at 6 sediment sampling sites along the Santos and São Vicente Estuary (Fig. 1). Three sites were located in the Santos Channel in the zone directly affected by the harbour and the industrial pole (SSV-1 to SSV-3); two were located in the São Vicente Channel (SSV-4 and SSV5), that is affected mainly by non-treated sewage; and one was located in the central portion of the Santos Bay (SSV-6), near the Santo's Submarine Sewage Outfall (SSOS). Thus distributed, the sampling sites used in this study reflect the different sources and origins of contamination.
Sediment samples were collected synoptically at depths ranging from 4 to $8 \mathrm{~m}$, in March 2004. The spatial sampling was designed on the basis of the results of previous studies (Abessa et al., 2001; Lamparelli et al., 2001) that showed the existence of sediment quality degradation gradient from the upper to the lower parts of the estuarine system. Replicate samples $(n=3)$ were collected from all stations. External control sediment was collected for the amphipod tests (Engenho D'Água Beach - Ilha Bela São Paulo). Intact sediment cores were collected by SCUBA divers, carefully capped and sealed underwater and held on ice in the dark during the transport to the laboratory. Only the top 3-5 cm layer of the superficial sediment was used. Sediments were stored at $4^{\circ} \mathrm{C}$ in the dark for no longer than two weeks, prior to toxicity testing. The control and dilution water used in the experiments consisted of natural seawater (35) collected in unpolluted areas (where the organisms were also collected) and filtered through a GFC Watman ${ }^{\circledR}$ filter.

Sediment Physical-Chemical Analysis

The sediment was dried at $60{ }^{\circ} \mathrm{C}$ prior to chemical analysis. Dried sediments were gently homogenized. Afterwards, the samples were totally digested in accordance with the method described by Loring \& Rantala (1992).

The concentrations of $\mathrm{Zn}, \mathrm{Cd}, \mathrm{Pb}, \mathrm{Cu}, \mathrm{Ni}$, Co and $\mathrm{V}$ in the sediments were determined by differential pulse anodic stripping voltametry (DPASV). Measurements were taken with a hanging mercury drop electrode (HMDE), using a Methrom 693 processor and the respective applications bulletins $\left(\mathrm{n}^{\circ}\right.$ 147-Methrom for $\mathrm{Zn}, \mathrm{Cd}, \mathrm{Pb}$ and $\mathrm{Cu}$; Methrom Application $n^{\circ} \mathrm{V}-81$ for $\mathrm{V}$ ). The quantification of the metal concentration was performed using the standard addition procedure by means of standard solutions for each metal (Titrisol, Merck). The analytical procedure for solid extracts was checked with the use of reference material (MESS-1 NRC and CRM 277 BCR), allowing agreement values greater than $90 \%$ for the certified sediments. Polycyclic aromatic hydrocarbons (PAHs) and polychlorinated biphenyls (PCBs) were analyzed by using gas chromatography equipment fitted with an electron capture detector (ECD) (U.S. Environmental Protection Agency method 8080). All the analytical procedures were checked with reference materials (Marine Sediment References Material for Trace Metals-1, National Research Council (NRC), Certified Reference Material, 277 BCR, and Conceil National de Researches Canada, 277 BCR, for heavy metals; and NRCpCNRC HS-1 for organic compounds) and allow agreement with certified values higher than $90 \%$. 
Grain size distribution was determined by standard mechanical dry sieve-shaker techniques to determine the sand, silt and clay fractions (Buchanan, 1984). Organic carbon (OC) content was determined using the titration method in accordance with of $\mathrm{El}$ Rayis's (1985) modification based on the acidification of the sediment sample.

\section{Amphipod Toxicity Test}

The Platyischnopid amphipod Tiburonella viscana inhabits the upper layers of clean or muddy sands from midwater level to $65 \mathrm{~m}$ depths and is common on the coast of São Paulo State. Organisms and negative control sediment were collected from sand-banks along the Engenho D'Água Beach, São

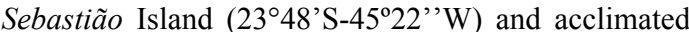
for 3 days in the laboratory. Amphipod sediment toxicity tests were conducted in accordance with the method described by Melo \& Abessa (2002). The test chambers were filled to $2 \mathrm{~cm}$ depth with the test sediments and filtered seawater up to $750 \mathrm{ml}$ and then maintained overnight at $25 \pm 2{ }^{\circ} \mathrm{C}$ with gentle aeration. On the next day, 10 adult, healthy amphipods were added to each test chamber and the test begun. Four replicates per test sediment were prepared. The tests were conducted at $25 \pm 2^{\circ} \mathrm{C}$, under constant aeration and lighting. After ten days, the contents of the chambers were gently sieved through a $0.5 \mathrm{~mm}$ screen and the surviving amphipods counted. Missing organisms were considered dead. The dissolved oxygen concentration, salinity and $\mathrm{pH}$ of the overlying water in the test chambers were measured at the beginning and end of the test.

\section{Statistical Analysis and Multivariate Approach}

Toxicity data were checked for normality and homoscedasticity assumptions with ShapiroWilk's and Bartlett's tests, respectively. The amphipod mortalities were compared by the one-way analysis of variance (ANOVA), followed by Dunnet's t'test. These analyse were carried out with the statistical package Toxstat ${ }^{\mathbb{B}}$ V.3.3 (Gulley et al., 1991).

Contamination and toxicity data were analyzed by factor analysis using principal component analysis (PCA), a multivariate statistical technique for the exploration of variable distributions as the extraction procedure. The original data set used in the analysis included nine chemical concentrations, one toxicity endpoint, organic carbon and fines. Factor analysis was performed on the correlation matrix, that is, the variables were autoscaled (standardized) so as to be treated as of equal importance. All analyses were performed using the PCA option of the MULTIVARIATE EXPLORATORY TECHNIQUES procedure, followed by the basic set-up for FACTOR
ANALYSIS procedure from the STATISTICA software tool (Stat Soft, Inc. 2001; version 6). For such analyses, the following data were used: total concentrations of $\mathrm{Zn}, \mathrm{Cd}, \mathrm{Pb}, \mathrm{Cu}, \mathrm{Ni}, \mathrm{Co}, \mathrm{V}, \mathrm{PCBs}$ and PAHs, OC content, grain size distribution and toxicity (amphipod mortality)

\section{Results And Discussion}

$$
\text { Sediment Physical-Chemical Analysis }
$$

Results obtained for sediment contamination and physical-chemical parameters are summarized in Table 1. Sediment samples tended to present relatively similar granulometric characteristics, with percent of fines ranging between 2 and $5 \%$, excepting the sediments from SSV-3 and SSV-6, which presented higher contents of fines (approximately 10\%). The result for the sediments from SSV-2 and SSV-3 differs from those obtained previously by Abessa (2002) for the same region. For other samples, both studies agreed, especially as regards SSV-6, where the higher levels of fines are due to the precipitation of particles discharged by the SSOS. According to Abessa et al. (2005), the sewage outfall emits suspended solids at above the maximum rate permitted for effluents under Brazilian law. Organic carbon contents in the sediments ranged from $0.8 \%$ to $4 \%$. Higher levels were found in the sediments collected in the estuary, indicating the influence of the mangroves and the sewage disposal in the organic enrichment of the sediments in the system.

The concentrations of metals in the sediments from the internal portion of the estuary (SSV-2; SSV-3 and SSV-4), where the Santos harbour and the industrial zone are located, were higher than those measured in the samples from the lower estuary and Santos Bay (SSV-1; SSV-5 and SSV-6). The metals contents exceeded the limits established by the Brazilian Legislation for Dredged Sediments (CONAMA $n^{\circ} .344$; Brazil, 2004) for the samples from stations SSV-2 $(\mathrm{Cu}, \mathrm{Pb}$ and $\mathrm{Zn})$ and SSV-3 $(\mathrm{Cu})$. These results corroborate those obtained previously (Abessa, 2002; Lamparelli et al., 2001), which showed the same distribution pattern of pollutants for this area. According to Lamparelli et al. (2001), the most internal portion of the estuary (represented by SSV-3 in this study) is affected by the Cubatão River, which receives most of the effluents from the Cubatão industrial complex. Thus this area receives the major contribution of chemicals. Moreover, Abessa (2002) found high concentrations of metals in the area close to the SSV-2, suggesting that such levels were due to industrial discharges. Other sources of the pollutants of the estuary are the old industrial and domestic landfills, nowadays considered contaminated by the State Environmental Agency (Lamparelli et al., 2001). 
Table 1. Results of amphipod toxicity test and physical-chemical analysis in the sediments from Santos and São Vicente Estuary.

\begin{tabular}{|c|c|c|c|c|c|c|c|c|c|c|c|c|}
\hline \multirow{2}{*}{$\begin{array}{l}\text { Sampling } \\
\text { sites }\end{array}$} & \multirow{2}{*}{$\begin{array}{c}\text { Amphipod* } \\
\text { Mortality } \\
(\%) \\
\\
\text { Mean } \\
( \pm \text { sd) }\end{array}$} & \multicolumn{7}{|c|}{ Trace Metals (mg.kg ${ }^{-1}$ ) } & \multicolumn{2}{|c|}{ Organics } & \multicolumn{2}{|c|}{$\begin{array}{c}\text { Sediment } \\
\text { properties }\end{array}$} \\
\hline & & $\mathrm{Cd}$ & Co & $\mathrm{Cu}$ & $\mathrm{Ni}$ & $\mathrm{Pb}$ & $\mathrm{V}$ & $\mathrm{Zn}$ & $\begin{array}{c}\text { PAH's } \\
\left(\mathrm{mg} \cdot \mathrm{kg}^{-1}\right)\end{array}$ & $\begin{array}{c}\text { PCB's } \\
\left(\mu \mathrm{g} \cdot \mathrm{kg}^{-1}\right)\end{array}$ & $\begin{array}{l}\text { O.C } \\
(\%)\end{array}$ & $\begin{array}{c}\text { Fines } \\
(\%)\end{array}$ \\
\hline SSV-2 & $72.5 \pm 5.0$ & $<0.1$ & $<0.1$ & 167.2 & 2.96 & 66.2 & 24.0 & 154.2 & 0.518 & 4.00 & 1.24 & 4.46 \\
\hline SSV-3 & $77.5 \pm 12.6$ & $<0.1$ & $<0.1$ & 157.7 & 4.49 & 22.1 & 87.8 & 110.4 & 0.425 & 2.61 & 2.78 & 9.68 \\
\hline SSV-4 & $80.0 \pm 11.5$ & $<0.1$ & $<0.1$ & 69.0 & 3.83 & 14.9 & 104.8 & 66.8 & 0.950 & 0.94 & 2.82 & 2.67 \\
\hline SSV-6 & $67.5 \pm 9.6$ & $<0.1$ & $<0.2$ & $<0.1$ & 6.02 & 14.6 & $<0.1$ & 53.2 & 0.600 & $<0.1$ & 1.00 & 11.56 \\
\hline
\end{tabular}

* Amphipod species - Tiburonella viscana.

These landfills, a consequence of illegal industrial and domestic waste disposal in recent decades, are scattered around the estuary and may be another considerable source of contamination - via superficial drainage or leachates - of the inner parts of the estuary. The central portion of the Santos Channel also receives a constant influx of chemical contaminants because of the activities of Santos harbour (Lamparelli et al., 2001). Abessa (2002) proposed that both regions should be considered highly polluted as regards metal contamination, and our data corroborate that author's suggestion.

The results obtained for PAHs and PCBs showed the same trend as that observed for the metals. According to Lamparelli et al. (2001), the sources of PCBs for the Santos and São Vicente Estuarine Complex may be the substances used or produced by the industrial processes (such as Ascarel and Arochlor) and the atmospheric deposition of PCBs released into the air by factories. In the present study, the sediments collected in the areas close to the industrial complex (stations SSV-2 and SSV-3) showed the highest values of PCBs, thus corroborating the results obtained by Lamparelli et al. (2001).

The highest concentration of PAHs was measured in the sediments from station SSV-4, located at the mouth of the Piaçabuçu River. Abessa (2002) also found a high concentration of PAHs in sediments in the same area. This river (Piaçabuçu) receives domestic sewage in natura and the river basin drains areas affected by old illegal industrial landfills, which are contaminated by a variety of chemicals. According to Lamparelli et al. (2001), both sources may contribute to the introduction of PAHs into this area. Moreover, sediments from stations SSV-2 and SSV-3 also presented high concentrations of PAHs, probably due to industrial and port activities. The contamination of these areas has already been registered in previous works (Abessa et al., 2001; Lamparelli et al., 2001; Medeiros \& Bícego, 2004).

\section{Amphipod Toxicity Test}

Results of the whole sediment toxicity test using Tiburonella viscana are given in Table 1. Mean amphipod mortality (10-day exposure) ranged from $80 \%$ at SSV-4 to $25 \%$ at SSV-1. Sediments from almost all the stations were considered toxic to $T$. viscana $(\mathrm{p}<0.05)$, excepting the sample from station SSV-1, which was not significantly different from the negative control (Engenho D'água beach). Water quality data $\left(\mathrm{T}^{\circ} \mathrm{C}, \mathrm{D} . \mathrm{O}\right.$., salinity, and $\left.\mathrm{pH}\right)$ were kept constant and within the acceptable limits (Melo \& Abessa, 2002) during the experiment.

The results obtained in this investigation for sediment toxicity are in accordance with previous data for the Santos and São Vicente Estuary (Abessa, 2002; Abessa et al., 1998; 2001). The toxicity of the sediments from SSV-2 and SSV-3 was clearly related to the port operations and industrial activity. According to the authors mentioned above, the sediments from the Santos Channel have frequently been toxic, even since the first studies conducted in this area and despite the removal of superficial sediments from the channel by routine dredging. Moreover, these two sites presented the highest levels 
of contaminants in the present study, which explains the toxic effects on the amphipods. The toxicity of the sediments from SSV-4 was probably related to the contamination sources previously mentioned for the São Vicente Channel (i.e., untreated domestic sewage released into the Piaçabuçu River and waste disposal landfills). This sample presented the highest levels of PAHs, which may have caused the toxicity. Among the significant toxic sediments, SSV-1 and SSV-5 showed the lowest mortality. Although the contamination levels at this site were not high, Abessa et al. (2005) found the toxicity to be associated with the high levels of detergents in the sediments from that place, thus evidencing that the discharge of untreated sewage affects the sediment quality. Thus, the sewage was probably a further cause of the toxicity of the sample from station SSV-6, located close to the SSOS diffusers. Rachid (2002) conducted a Phase 1 TIE study using porewater from that site, and showed that toxicity was mainly caused by volatile substances, metals, ammonia and organic compounds, whereas Abessa (2002) and Lamparelli et al. (2001) attributed the toxicity to some specific contaminants such as chlorines, detergents, ammonia, sulphur and mercury. The results of our study partially corroborate with those previous findings above.

\section{Multivariate Analysis Approach}

The multivariate method (factor analysis) provides a deeper insight into the structure of complex and diverse data (Riba et al., 2003). For example, this multivariate tool has revealed groupings of varying degrees of correlation between chemical concentrations in sediment and their biological effects. Chemical concentrations in sediments have been associated by PCA with toxicity to amphipods, the indicator of biological effects (Table 2). Such factors have been used to explain $84.7 \%$ of the variance in the original data set. The first principal factor, PC1 accounted for $41.9 \%$ of the variance. This factor is correlated with the chemical concentrations of PCBs, $\mathrm{Cu}, \mathrm{Pb}, \mathrm{Zn}$ and toxicity. The second factor, $\mathrm{PC} 2$, accounted for $24.28 \%$ of the variances and combined O.M. and V contents. This factor represented the association of the organic carbon and vanadium in sediments (with higher loadings) but not those associated with biological response. Finally, the third factor accounted for the lowest variance $(18.41 \%)$ and associated the toxicity (higher than in factor 1), PAHs and fines with higher loadings. This factor suggested that the biological effect could be related to the concentrations of PAHs associated with fines, although their concentrations are below those established by Brazilian Legislation for Dredged Sediments (CONAMA n ${ }^{\circ} .344$; Brazil, 2004) as toxic.
To confirm these factor descriptions and to establish preliminary effect threshold values for sediment contamination for the Santos and São Vicente Estuary and Bay, the representation of estimated factor scores from each station was used (Fig. 2). Factor 1 scores were negative for stations SSV-1, SSV-4, SSV-5 and SSV-6. On the other hand, the positive scores of factor 3 measured at stations SSV-3, SSV-4 and SSV-6, confirmed that this factor was related to the association of biological effect with $\mathrm{PAH}$ concentrations.

Table 2. Sorted rotated factor loadings (pattern) of the original 10 variables. The loading matrix has been rearranged so that the columns appear in decreasing order of variance explained by factors. Loadings greater than 0.32 are highlighted (bold type). Factors are numbered consecutively from left to right in order of decreasing variance explained.

\begin{tabular}{cccc}
\hline \hline Variable & Factor 1 & Factor 2 & Factor 3 \\
\hline \% Variance & 41.99 & 24.28 & 18.41 \\
$\mathrm{Cu}$ & $\mathbf{0 . 8 8}$ & 0.15 & $\mathbf{0 . 3 7}$ \\
$\mathrm{Ni}$ & -0.82 & -0.10 & $\mathbf{0 . 3 5}$ \\
$\mathrm{Pb}$ & $\mathbf{0 . 9 1}$ & -0.24 & $-0,04$ \\
$\mathrm{~V}$ & 0.19 & $\mathbf{0 . 8 4}$ & 0.31 \\
$\mathrm{Zn}$ & $\mathbf{0 . 9 1}$ & 0.07 & 0.21 \\
$\mathrm{PAHs}$ & 0.14 & 0.15 & $\mathbf{0 . 7 6}$ \\
PCBs & $\mathbf{0 . 9 7}$ & -0.02 & 0.11 \\
O.C. & -0.07 & $\mathbf{0 . 9 4}$ & -0.07 \\
Fines & -0.20 & -0.22 & $\mathbf{0 . 7 6}$ \\
Toxicity & $\mathbf{0 . 4 2}$ & 0.16 & $\mathbf{0 . 8 7}$ \\
\hline
\end{tabular}

For the chemicals grouped with their highest loadings in factor 1 ( $\mathrm{PCBs}, \mathrm{Cu}, \mathrm{Pb}$ and $\mathrm{Zn}$ ) and in factor 3 (PAHs), the estimation of such effect threshold values in accordance with the procedures reported by DelValls et al. (1998) for Sediment Quality Values (SQVs). This approach is based on the comparison of the chemicals and the toxicity of their respective groups, i.e., in this case, factors 1 and 3 . The assumption is that these chemicals are presumably correlated in a cause-and-effect relationship. Thus, when the scores of factors 1 and 3 (probable correlation between the chemicals and biological adverse effects) are 0 or below (Fig. 2), the maximum 

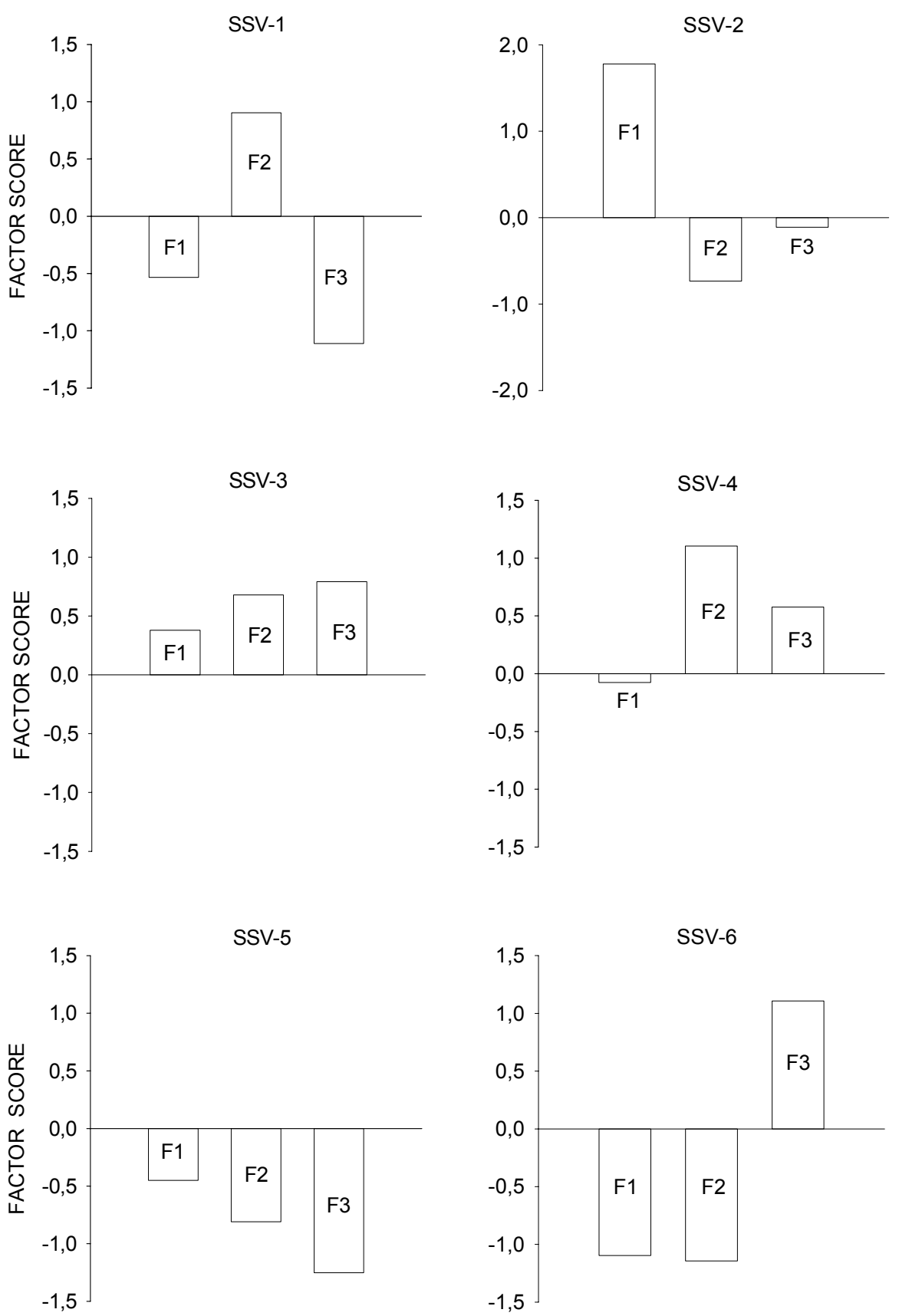

Fig. 2. Estimated factor scores to the centroid from each of six stations. The factor scores quantify the influence of each component (contaminant) on the toxicity at each station and are used to confirm the factor description. 
concentrations of toxic chemicals at any of those stations represent the maximum chemical concentrations that are not associated with adverse effects. These are considered to be concentrations below which biological effects are low or minimal and are here indicated as not polluted. By contrast, to establish the minimum concentrations above which biological effects are always high, those minimal concentrations where factor scores from factors 1 and 3 were higher than 0 were selected and described here as highly polluted. Also, an intermediate range of chemical concentrations representing an area of uncertainty, between the high and low concentrations, is described as moderately polluted. These three classes of sediment toxicity-contamination associations may be better identified from Table 3 .

Table 3. Summary of the estimated effect threshold values for sediment contamination in the Santos and São Vicente Estuarine System for the metals $\mathrm{Cu}, \mathrm{Pb}$ and $\mathrm{Zn}\left(\mathrm{mg}_{\mathrm{kg}}{ }^{-1}\right)$, total polycyclic aromatic hydrocarbons ( $\Sigma \mathrm{PAHs} ; \mathrm{mg}^{\mathrm{k}} \mathrm{kg}^{-1}$ ) and total polychlorinated biphenyls ( $\left.\Sigma \mathrm{PCBs} ; \mu \mathrm{g} \cdot \mathrm{kg}^{-1}\right)$.

\begin{tabular}{cccr}
\hline \hline $\begin{array}{c}\text { Chemical } \\
\text { study }\end{array}$ & Polluted & $\begin{array}{c}\text { Sodiment quality guideline } \\
\text { polluted }\end{array}$ & \multicolumn{1}{c}{$\begin{array}{c}\text { Area of } \\
\text { uncertainty }\end{array}$} \\
\hline $\mathrm{Cu}$ & $>157.7$ & $\leq 69.0$ & $157.7-69.0$ \\
$\mathrm{~Pb}$ & $>22.1$ & $\leq 17.4$ & $22.1-17.4$ \\
$\mathrm{Zn}$ & $>110.4$ & $\leq 73.3$ & $110.4-73.3$ \\
$\Sigma$ PAHs & $>0.6$ & $\leq 0.5$ & $0.6-0.5$ \\
$\Sigma$ PCBs & $>4.0$ & $\leq 0.9$ & $4.0-0.9$ \\
\hline
\end{tabular}

The results of this investigation showed that toxicity was closely related to the physical-chemical data, confirming the poorer sediment quality in the internal portions of the estuary, followed by the vicinity of the SSOS. Such results were in agreement with the literature on for this region (Lamparelli et al., 2001; Abessa, 2002). As a consequence, the dredging operations and the oceanic disposal of sediments from the Santos Channel should be monitored to estimate the effective damage of these activities to local marine ecosystems. Moreover, the factorial analysis used in this study to estimate effect threshold values for sediment contamination was considered useful and should continue to be used to derive Sediment Quality Values and/or Guidelines.

\section{AcKNOWLedgements}

Both authors with to express their thanks: the first, to CAPES/MEC-Brazil (BEX-2558/03-3) for the postdoctoral scholarship and R.B. Choueri to ERASMUS MUNDUS for the master's scholarship.

\section{REFERENCES}

Abessa, D. M. S.; Sousa, E. C. P. M.; Rachid, B. R. F. \& Mastroti, R. R. 1998. Use of the burrowing amphipod Tiburonella viscana as tool in marine sediment contaminantion assessment. Braz. arch. biol. technol., 41:225-230

Abessa, D. M. S.; Sousa, E. C. P. M.; Rachid, B. R. F. \& Mastroti, R. R. 2001. Sediment toxicity in Santos estuary, SP-Brazil: preliminary results. Ecotox. Environ. Rest., 4:6-9.

Abessa, D. M. S.; Carr, R. S.; Rachid, B. R. F.; Sousa, E. C. P. M.; Hortelani, M. A. \& Sarkis, J. E. 2005. Influence of a Brazilian sewage outfall on the toxicity and contamination of adjacent sediments. Mar. pollut. Bull., 50:875-885.

APHA - American Public Health Association, American Water Works Association, and Water Pollution Control Federation. 1992. Standard Methods $18^{\text {th }}$ ed. Washington, American Public Health Association.

American Society for Testing and Materials. 1997. Standard guide for conducting 10-day static sediment toxicity tests with marine and estuarine amphipods. E1367-92. In: Annual Book of ASTM Standards, Vol. 11.05. Philadelphia, PA. p. 731-756.

Boldrini, C. V. \& Navas-Pereira, D. 1987. Metais pesados na Baía de Santos e Estuários de Santos e São Vicente: Bioacumulação. Ambiente, 1(3):118-127.

Brazil. Resolução CONAMA No 344 , de 25 de março de 2004. Estabelece as diretrizes gerais e os procedimentos mínimos para a avaliação do material a ser dragado em águas jurisdicionais brasileiras, e dá outras providências. Conselho Nacional de Meio Ambiente (CONAMA), Brasília, DF.

Buchanan, J. B. 1984. Sediment analysis. In: Holme N. A. \& Mcintyre, A. D. eds. Methods for the study of marine benthos. Cambridge, Blackwell. p. 41-65.

Burton Jr, G. A. 1992. Assessing contaminated aquatic sediments. Environ. Sci. Technol., 26:1862-1875.

Carr, R. S.; Long, E. R.; Windom, H. L.; Chapman, D. C.; Thursby, G.; Sloane, G. M. \& Wolf, D. A. 1996. Sediment quality assessment studies of Tampa Bay, Florida. Environ. Toxicol. Chem., 15: 1218-1231.

Cesar, A.; Marín, A.; Vita, R. \& Marín-Guirao, L. 2000. Test de toxicidad con sedimento marino en la costa Mediterránea empleando anfípodos: Gammarus aequicauda y Microdeutopus gryllotalpa. In: Espíndola, G.; Paschoal; R.; Rocha, O.; Bohrer, C. \& Neto, L. eds. Ecotoxicologia: Perspectivas para o século XXI. São Carlos, Rima. p. 17-27.

CETESB - Companhia de Tecnologia de Saneamento Ambiental. 1985. Baixada Santista - Memorial Descritivo. Carta do Meio Ambiente e de sua dinâmica. Relatório Técnico. $33 \mathrm{p}$.

Del Valls, T. A.; Forja, J. M. \& Gómez-Parra, A. 1998. Integrated assessment of sediment quality in two littoral ecosystems of the gulf of Cádiz, Spain. Environ. Toxicol. Chem., 17:1073-1084.

El Rayis, O. A. 1985. Re-assessment of the titration method for determination of organic carbon in recent sediment. Rapp Comm. Int .Mediterr., 29:45-47. 
Fúlfaro, V. J.; Requejo, C. S.; Landim, P. M. B. \& Fúlfaro, R. 1983. Distribuição de elementos metálicos nos sedimentos da Baía de Santos, SP. In: Simpósio Regional de Geologia, 4. São Paulo, 1983. Atas. São Paulo, Sociedade Brasileira de Geologia. p. 275-289.

Gannon, J. E. \& Beeton, A. M. 1971. Procedures for determining the effects of dredge sediments on biota benthos viability and sediment selectivity tests. J. Wat. Pollut. Control. Fed., 43:392-389.

Gulley, D.; Boelter, A. M. \& Bergman, H. L. 1991 TOXSTAT ${ }^{\circledR}$ Computer Program, Version 3.3. Laramie, WY. University of Wyoming.

Hunt, J. W.; Anderson, B. S.; Phillips, B. M.; Tjeerdema, R. S.; Taberski, K. M.; Wilson, C. J.; Puckett, H. M.; Stephenson, M.; Fairey, R. \& Oakden, J. 2001a. A largescale categorization of sites in San Francisco Bay, USA, based on the sediment quality triad, toxicity identification evaluations, and gradient studies. Environ. Toxicol. Chem., 20:1252-1265.

Hunt, J. W.; Anderson, B. S.; Phillips, B. M.; Newman, J.; Tjeerdema, R. S.; Fairey, R.; Puckett, H. M.; Stephenson, M.; Smith, R. W.; Wilson, C. J. \& Taberski, K. M $2001 \mathrm{~b}$. Evaluation and use of sediment toxicity reference sites for statistical comparisons in regional assessments. Environ Toxicol. Chem., 20:1266-1275.

Lamparelli, M. L.; Costa, M. P.; Prósperi, V. A.; Bevilácqua, J. E.; Araújo, R. P. A.; Eysink, G. G. L. \& Pompeia, S. 2001. Sistema Estuarino de Santos e São Vicente. Relatório Técnico. São Paulo, CETESB. 178 p.

Loring, D. H. \& Rantala, R. T. T. 1992. Manual for the geochemical analyses of marine sediments and suspended particulate matter. Earth. Sci. Rev., 32:235283.

Medeiros, P. M. \& Bícego, M. C. 2004. Investigation of natural and anthropogenic hydrocarbon inputs in sediments using geochemical markers. I. Santos, SPBrazil. Mar. pollut. Bull., 49:761-769.

Melo, S. L. R. \& Abessa, D. M. S. 2002. Testes de toxicidade com sedimentos marinhos utilizando anfípodos. In: Nascimento, I. A.; Sousa, E. C. P. M. \& Nipper, M. G. eds. Métodos em ecotoxicologia marinha: aplicações no Brasil. São Paulo: Artes Gráficas e Indústria Ltda. p. 163-178.
Nipper, M. G.; Prósperi, V. A. \& Zamboni, A. J. 1993. Toxicity testing with coastal species of southeastern Brazil. Echinoderm sperm and embryos. Environ. Contamin. Toxicol., 50:646-652.

Riba, I.; Casado-Martinez, C.; Forja, J. M. \& DelValls, T. A. 2004. Sediment quality in the Atlantic coast of Spain. Environ. Contamin. Toxicol., 23:271-282.

Swartz, R. C.; DeBen, W. A.; Sercu, K. A. \& Lamberson, J. O. 1982. Sediment toxicity and the distribution of the amphipods in Commencement Bay, Washington, USA. Mar. Pollut. Bull., 13:359-364.

Tabachnic, B. G. \& Fidell, L. S. 1996. Using multivariate statistics. New York, Harper Collins, College Publishers.

U.S. Environmental Protection Agency. 1994. Methods for assessing the toxicity of sediment-associated contaminants with estuarine and marine amphipods. EPA-600-R-94-025. Washington, DC, 20460.

Weber, R. R. \& Bícego, M. C. 1987. Distribuição e origem dos hidrocarbonetos parafínicos de sedimentos de superfície da costa do Estado de São Paulo entre Ubatuba e Cananéia. In: Simpósio de Ecossistemas da Costa Sul e Sudeste Brasileira. Águas de Lindóia, SP., 1987. Anais. São Paulo, ACIESP, 2:307.336.

Sources of Unpublished Material

Abessa, D. M. S. 2002. Avaliação da Qualidade de Sedimentos do Sistema Estuarino de Santos, SP, Brasil. Phd. Thesis. Universidade de São Paulo, Instituto Oceanográfico. São Paulo. 290p.

Rachid, B. R. F. 2002. Avaliação ecotoxicológica dos efluentes domésticos lançados pelos sistemas de disposição oceânica da Baixada Santista. Phd. Thesis. Universidade de São Paulo, Instituto Oceanográfico. São Paulo. 286p.

(Manuscript received 09 August 2005; revised 19 November 2005; accepted 02 February 2006) 